\title{
MAXIMUM CAPACITIES OF DISTIBUTED GENERATIONS IN ORDER TO AVOID FAILURES OF THE OVERCURRENT RELAY COORDINATION ON A DISTRIBUTION NETWORK
}

\author{
Adrianti*, Rudy Prasetya \\ Jurusan Teknik Elektro, Fakultas Teknik, Universitas Andalas \\ "Corresponding author, e-mail : adrianti@ft.unand.ac.id
}

\begin{abstract}
The installation of a Distributed Generation (DG) in a distribution system often changes the direction and magnitude of current for normal and faulted conditions. The changes may affect the existing protection system hence it may not work as intended to after the installation. Since DG capacity is often small, it will not be economical to invest in the changing/replacement of the protection system. For that reason, this paper proposes a methodology to find maximum capacities of DGs that can be installed without cause failures to the existing protection operation and its coordination. A case study of a distribution network in West Sumatera is present to illustrate the methodology. The results show that the more downstream of buses from the grid, the less DG capacity that can be installed.
\end{abstract}

Keywords : Distributed generation, maximum capacity of DG, overcurrent relay, relay coordination

\begin{abstract}
Abstrak - Penempatan pembangkit tersebar (DG) di jaringan distribusi sering kali mengubah arah dan besar arus baik saat kondisi normal maupun kondisi gangguan. Perubahan tersebut bisa mempengaruhi sistem proteksi yang sudah terpasang, sehingga sistem proteksi tersebut mungkin tidak bekerja seperti yang diharapkan setelah pemasangan DG. Karena kapasitas DG umumnya kecil maka penggantian sistem proteksi untuk mengatasi masalah proteksi tersebut akan menjadi tidak ekonomis. Denga alasan tersebut, tulisan ini mengusulkan sebuah metode untuk mencari maksimum kapasitas DG yang dapat dipasang tanpa menyebabkan kegagalan operasi dan koordinasi sistem proteksi yang sudah ada. Studi kasus di jaringan distribusi Sumatera Barat digunakan untuk mengilustrasikan metodologi yang diusulkan. Hasil penelitian menunjukkan bahwa semakin ke hilir suatu bus dari grid maka semakin kecil kapasitas DG yang dapat dipasang.
\end{abstract}

Keywords : Pembangkit tersebar, kapasitas maksimum DG, relai arus lebih, koordinasi relai

Copyright $\odot 2016$ JNTE. All rights reserved

\section{INTRODUCTION}

Utilization of Distributed Generation (DG) is considered as one of solution for environment problem due fossil fuel carbon emission and the need for higher capacity of transmission lines [1] DGs also have capability to provide better performance than conventional generation such as reducing electrical loss, improving voltage magnitude [2] and possibility to increase distribution reliability. However, the presence of a DG in a distribution network often bring a new problem for power system protection that already exist before the installation of the DG [3].

DGs can change the direction of current in distribution networks from single radial direction into multi direction. The change can occur both for normal and faulted condition. The protection systems which already exist before the installation of DGs, may not successfully cope with the new condition hence fail to work as intended to.

Since the capacity of a DG is usually small, hence it may not be cost-effective to change the protection system after the installation of a DG. Especially if it requires new devices as the existing devices cannot handle the new condition. Therefore, this study tries to find a condition where the installation of a DG does not cause a significant change which requires a change in protection system/settings. The result of the study is intended to give a recommendation to the distribution network provider about the maximum capacity of a synchronous base DG in certain position in the network which will not alter the existing protection system.

This paper is started with the effect of DG to normal current flows in the network then 
followed by the effect to the magnitude and direction of fault currents. The methodology for this research is explained and the results provide recommendations for the maximum capacity of DGs. The paper is finished with conclusions.

\section{EFFECT OF DG TO NORMAL CURRENT FLOWS IN THE NETWORK}

A radial distribution network is designed with assumption that electrical current flow in a direction from the grid to the downstream network. Installation of DG may alter the current flow direction if DG output exceeds the local demand. For this condition, DG exports power to the upper section of the network or even to the grid.

Protection systems in distribution networks are generally current magnitude base devices such as overcurrent relay, fuse and recloser. If DG export power is relatively high hence the reverse current that seen by local protection relay is greater that the relay setting, the protection device will operate for this no fault condition.

The setting of overcurrent relay for example, is only slightly greater that the maximum normal current in the distribution line, as shown by the formula in equation (1) [4]. Therefore, it will trip whenever the flowing current in the feeder exceed the setting.

$$
I_{\text {set }}=\beta \times I_{\text {max }}
$$

Where:

$$
\begin{aligned}
& I_{\text {set }} \quad=\text { primary current setting for } \\
& \text { overcurrent relay } \\
& I_{\max }=\text { maximum load current in the line } \\
& \beta \quad=\text { current } \operatorname{margin}=1.05-1.3
\end{aligned}
$$

This condition can be overcome by increase the relay setting or replace the relay into directional relay. The former will have impact to the coordination with other relays; therefore it will need to re-set the entire overcurrent relay in the network in order to establish a new relay coordination. The latest will be an expensive choice as it will require installation new devices.

\section{THE EFFECT OF DG TO THE MAGNITUDE OF FAULT CURRENTS IN THE NETWORK}

Synchronous machine base DGs supply fault current to the network when a fault occurs in the distribution system. While other types of DG contribute very small or even zero fault current $[5,6]$. Therefore, when a synchronous machine base DG is connected to a distribution network, the fault current in the faulted point will increase. For this reason, the type of DGs that will be considered in this paper is DG with synchronous generator.

Although, DGs increase fault current in the faulted point, fault current seen by protection relays in the network may increase or reduce depending the position of DGs and the faulted section. The changes of fault current seen by the relays may cause failures of the relays to operate or even unwanted operation for an external fault of their protected zone.

In general, there are different effects of DG to the fault current seen by the relay which list as follows:

1. Position of DG is downstream of the relay and fault occurs downstream of the DG as in figure 1. Additional fault current is supplied by the DG along with the supply from the grid. For this condition, the relay that upper stream of the DG will see less fault current than when DG does not exist. It may cause the relay fails to operate

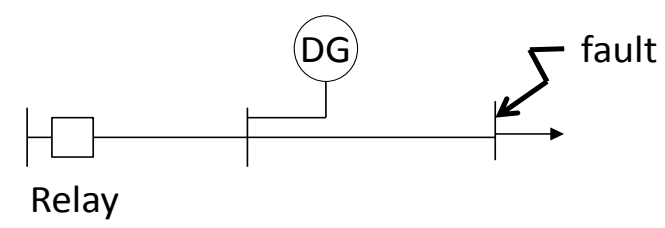

Figure 1. DG and fault downstream of the Relay

2. Position of the DG is on the next feeder of the faulted section as shown in figure 2. For this condition R2 should trip. However as the DG supplies fault current to the faulted section, $\mathrm{R} 1$ will also see the high current from the DG hence it may also trip.

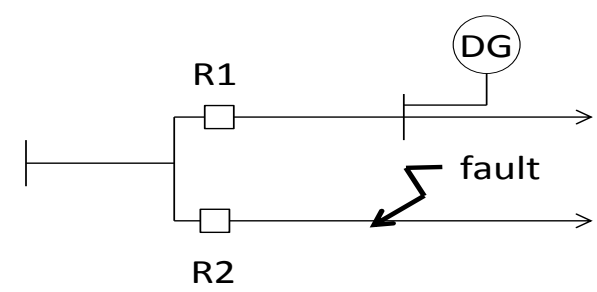

Figure 2. Fault on the adjacent feeder of DG 


\section{RESEARCH METHODOLOGY}

In order to make the recommendation of maximum DG capacity which avoid failure of the distribution line protection system, distribution system simulation is performed. The simulation is carried out using ETAP 12.6.0 [7].

Step of the simulation is as follows:

1. Start

2. Create the single line diagram of the distribution system in ETAP 12.6.0

3. Perform power flow simulation

4. Perform fault simulation

5. Set the invers overcurrent relay settings in the network and make sure the relay coordination is good by testing it with Star-Protective Device Coordination

6. Install a DG with relatively big capacity (5MW for example) on a node in the system

7. Perform power flow, check current flow on the lines, and compare with the associated relay settings

8. If the current is greater than the setting, reduce the DG capacity and go to step g, otherwise, go to step i.

9. Perform relay coordination testing for different fault position in the network, especially for condition in section 3 above. If the relay coordination is violated, reduce the DG capacity and repeat step i. Otherwise, set the DG capacity as the maximum capacity on that node. Go back to step e for different node of DG position.

10.Have all the candidate note of DG position tested? If yes go to $\mathrm{k}$, otherwise go to $\mathrm{f}$

11. Make conclusion of the DG maximum capacities.

12.End

\section{RESULTS AND DISCUSSSION}

A case study for this research is a radial distribution network as shown in figure 3 . The network is a modified distribution network of Substation Tanjung Ampalu in Sijunjung, West Sumatera [8].

The current and time setting of the relay for each feeder is shown in table 1 . The maximum capacity of DG is observed for the installation on bus $2,3,4,5$ and 6 , once at a time.

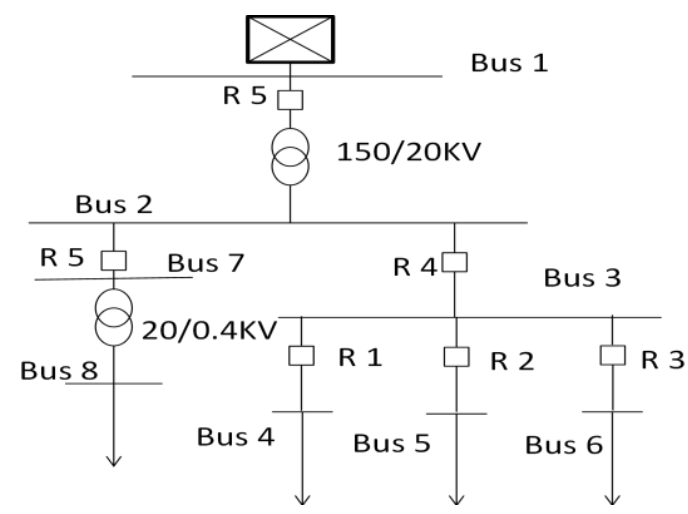

Figure 3. Single line diagram of the distribution network case study

When a $5 \mathrm{MW}$ DG is installed at bus 2, the DG exports power to the grid with nominal current higher than the relay 5 (R5) setting. This will cause tripping of R5 for no fault condition which should not happen. The maximum capacity of the DG on bus 2 which does not exceed the relay settings is $4 \mathrm{MW}$. Coordination of the relays after installation 4 MW DG on bus 2 works well for any location and types of the faults. Therefore, the maximum capacity of DG on bus 2 is $4 \mathrm{MW}$.

Tabel 1. Overcurrent relay settings of the feeders

\begin{tabular}{|c|c|c|}
\hline Relay & Iset (A) & TMS \\
\hline R1 & 30.58 & 0.061 \\
\hline R2 & 28.27 & 0.062 \\
\hline R3 & 13.31 & 0.073 \\
\hline R4 & 72.16 & 0.244 \\
\hline R5 & 2.09 & 0.471 \\
\hline R6 & 9.9 & 0.579 \\
\hline
\end{tabular}

For bus 3, the maximum capacity of DG which cause the exported current flow below the relay settings are $4 \mathrm{MW}$. However, this DG capacity cause false in relay coordination, i.e. fault on bus 7 results in unwanted trip of R4 before R5 trip. The unwanted trip also occurs for smaller capacity of the DG, but for the capacity 2 MW or smaller, the unwanted operation does not occur. Therefore, the maximum capacity that can be recommended is $2 \mathrm{MW}$ on bus 3 .

Installation a DG in bus 4,5 or 6 causes unwanted trip of R1, R2 or R3 respectively for a fault on bus 7. Any capacities of the DG trigger trip operation of the nearest relay of the DG for faults on bus 7. Therefore, the installation of a DG on bus 4, 5 or 6 is not recommended, or the relay settings need to be adjusted. 
Summary of the maximum DG capacities for installation on different bus is shown in table 2 . All the problems in table 2 are the unwanted operation of the relays

Table 2. The recommended maximum capacity of DG

\begin{tabular}{|c|c|c|}
\hline DG position & Max Capacity & Restricted by relay \\
\hline Bus 2 & $4 \mathrm{MW}$ & R5 \\
\hline Bus 3 & $2 \mathrm{MW}$ & $\mathrm{R} 4$ \\
\hline Bus 4 & 0 & R1 \\
\hline Bus 5 & 0 & R2 \\
\hline Bus 6 & 0 & R3 \\
\hline
\end{tabular}

\section{CONCLUSION}

DG offer several benefit to electrical power system. However, since the capacity of a DG is small, benefit from each DG is relatively small. Therefore, if the installation of a DG requires a lot of changes in the existing protection system, it will be necessary to conduct a further study to examine whether the DG installation is costeffective. From the case study, it has been found that installation of DG on bus 4,5 and 6 will definitely disturb the existing overcurrent relay $\mathrm{R} 1, \mathrm{R} 2$ and $\mathrm{R} 3$ respectively. While installations on other buses are restricted to maximum $2 \mathrm{MW}$ on bus 3 and $4 \mathrm{MW}$ on bus 2 . From the results, it can be conclude that the maximum capacities of DGs that can be installed are lesser as the position of the installation goes further downstream from the grid.

Suggestion for further studies is to analyze the effect of the increasing normal and fault current due DG installation to the hosting capacity of network components such as transformers, circuit breakers and distribution line. As mention before, there is a need to perform cost and benefit analysis if installation of a DG requires changes in protection system.

\section{REFERENCES}

[1] N. Jenkins, Distributed generation: The Institution of Engineering and Technology, 2010.

[2] E. Fitrianto and R. Nazir, "Efek Pengintegrasian Pembangkit Listrik Tersebar pada Jaringan Distribusi Radial terhadap Perosotan Tegangan," JNTE, vol. 5, pp. 1-6, 2016.

[3] P. T. Manditereza and R. Bansal, "Renewable distributed generation: The hidden challenges - A review from the protection perspective," Renewable and Sustainable Energy Reviews, vol. 58, pp. 1457-1465, 2016.

[4] Alstom-Grid. (2011). Network Protection \& Automation Guide. Available: http://www.alstom.com/grid/productsand-services/Substation-automationsystem/protection-relays/NetworkProtection-Automation-Guide-NEW2011-Edition/

[5] M. H. Bollen and F. Hassan, Integration of distributed generation in the power system vol. 80: John Wiley \& Sons, 2011.

[6] N. Tleis, Power systems modelling and fault analysis: theory and practice: Newnes, 2007.

[7] ETAP. (2015, 4/10/2016). ETAP Product overview.

Available:

http://etap.com/Documents/Download\%2 OPDF/etap-product-overview-HQ2015.pdf?lang=en-US

[8] Zulkarnaini and E. S. H, "Evaluasi Koordinasi Relay Proteksi pada Feeder Distribusi Tenaga Listrik (GH Tanjung Ampalu Sijunjung)," Jurnal Teknik Elektro ITP, vol. 1, Januari 20122012.

Adrianti, is currently a lecturer at Electrical Engineering Department, Universitas Andalas, Padang, Indonesia. She completed her undergraduate study at Universitas Sriwijaya and master degree at Institut Teknologi Bandung. She finished her $\mathrm{PhD}$ study at University of Strathclyde, Glasgow, UK in 2015.

Rudy Prasetya, finished his undergraduate study at Electrical Engineering, Universitas Andalas in 2016 